\title{
International-Legal Problem of Space Debris
}

\author{
Vasyl Semenyaka
}

\author{
Ph.D., Senior Researcher, V.M.Koretsky Institute of state \\ and law of the National Academy of Sciences of Ukraine (Kyiv, Ukraine) \\ E-mail: v.semenyaka@ukr.net
}

The article deals with theoretical and practical legal aspects of the problem of man-made clogging of near-Earth space. The analysis shows that international space law does not cope with the current challenges and threats associated with man-made clogging of outer space. It has been shown that the Guiding Principles on the Prevention of the Development of Space Debris are not legally binding and subject to the use of the State exclusively on a voluntary basis. The necessity of forming an international legal mechanism for the protection of outer space from man-made clogging arises. The necessity of forming an international legal mechanism for the protection of outer space from man-made clogging arises. The necessity of developing and concluding the Convention on the prevention of the formation of space debris and the purification of near-Earth space is substantiated.

Keywords: outer space; clogging of outer space; space debris; space law; spacecraft.

\section{Міжнародно-правова проблема космічного сміття}

\section{Семеняка, Василь Васильович}

Кандидат юридичних наук, старший науковий співробітник

Інституту держави і права ім. В.М. Корецького НАН України

(Київ, Україна)

\begin{abstract}
У статті досліджуються теоретичні і практичні правові аспекти проблеми техногенного засмічення навколоземного космічного простору. Проведений аналіз свідчить, щцо міжнародне космічне право не справляється з сучасними викликами та загрозами, пов 'язаними з техногенним засміченням космічного простору. Показано, що Керівні принциипи щодо запобігання утворення космічного сміття не мають обов 'язкової юридичної сили і підлягають застосовуванню держави виключно у добровільному порядку. Доводиться необхідність формування міжнародно-правового механізму охорони космічного простору від техногенного засмічення. Обгрунтовується потреба розробки і укладання Конвенції про запобігання утворення космічного сміття та очищення навколоземного космічного простору.
\end{abstract}

Ключові слова: космічний простір; засмічення космічного простору; космічне сміття; космічне право; космічний апарат.

(C) Semenyaka, Vasyl, 2018 
Received: January 6, 2018; accepted: February 1, 2018

Advanced Space Law, Volume 1, 2018: 84-90

https://oi.org/10.29202/asl/2018/1/10

\section{Постановка проблеми}

Світова практика провадження космічної діяльності свідчить, що в період з 19572018 pp. у навколоземний космічний простір запущено 8378 космічних об’єктів різноманітного цільового призначення [Online Index, 2018]. При цьому загальна кількість каталогізованих космічних об'єктів, які знаходяться в космічному просторі, становить 17815 космічних об’єктів, з яких лише 1503 — це функціонуючі космічні апарати (зокрема, метеорологічні, телекомунікаційні, навігаційні супутники, космічні апарати дистанційного зондування Землі). Решта космічних об’єктів (16 312) — космічне сміття, що включає нефункціонуючі космічні апарати -2736 , розгінні блоки і останні ступені ракет-носії - 1 954, фрагменти цих об’єктів та операційні елементи запусків - 11622 [События, 2016: 7].

Космічне сміття несе потенційну загрозу для суб'єктів космічних правовідносин, оскільки існує імовірність ризику зіткнення об'єктів космічного сміття з функціонуючими космічними апаратами та/або космічними об’єктами, що запускаються. Не виключаються ризики неконтрольованого падіння космічного сміття на Землю та заподіяння шкоди фізичним і юридичним особам, забруднення навколишнього середовища. Особливу небезпеку становлять зіткнення та падіння космічних апаратів з ядерними джерелами енергії на борту.

Практика свідчить про непоодинокі випадки фрагментації космічних об'єктів, яка відбувається унаслідок їхнього зіткнення, вибухів тощо. Розпадання космічних об'єктів на дрібні частини сприяє збільшенню космічного сміття. Водночас зростають ризики виникнення спірних ситуацій між суб'єктами космічної діяльності по факту зіткнення космічних об'єктів з космічним сміттям тощо.

Теперішнє заповнення навколоземного космічного простору об'єктами космічного сміття є однією з глобальних проблем, оскільки засмічення становить реальну загрозу реалізації міжнародних та національних космічних проектів і програм. Об'єкти космічного сміття через 30-40 років можуть паралізувати діяльність у сфері дослідження та використання космічного простору, включаючи Місць та інші небесні тіла [Сборник, 2013: 95].

Необхідність розв'язання міжнародно-правової проблеми забезпечення охорони навколоземного космічного простору від техногенного засмічення надзвичайно актуалізується у світлі інтенсифікації господарської діяльності, пов'язаної з безпосереднім дослідженням та використанням космічного простору. Тому цілком закономірним $є$ віднесення проблеми техногенного засмічення космічного простору до категорій актуальних питань у галузі міжнародного та національного космічного права.

У вітчизняній та зарубіжній юридичній літературі фактично відсутні розробки щодо міжнародно-правової проблеми космічного сміття. У роботах Ю.С. Шемшученко, Н. Р. Малишевої, О. В. Бєглого, С. П. Малкова та Г. П. Жукова розглядались окремі правові аспекти техногенного засмічення навколоземного космічного простору. 
Метою статті є дослідження міжнародно-правової проблеми запобігання утворення та видалення космічного сміття, визначення можливих напрямків її вирішення $з$ метою охорони навколоземного космічного простору від техногенного засмічення.

\section{Виклад основного матеріалу}

Термін «космічне сміття» з'явився у лексиконі космічного права фактично із початком провадження космічної діяльності з дослідження та використання космічного простору, включаючи Місяць та інші небесні тіла. Щоправда в міжнародному космічному праві відсутнє його офіційне визначення. На доктринальному рівні термін «космічне сміття» використовується для означення усіх нефункціонуючих антропогенних об'єктів, включаючи їхні фрагменти та елементи, що перебувають на навколоземній орбіті або повертаються в атмосферу Землі [Шемшученко, 2012: 109].

Основними причинами техногенного засмічення навколоземного космічного простоpy $\epsilon$ :

- фрагментація космічної техніки в результаті руйнування;

- викиди у космічний простір операційний елементів космічних апаратів (пружин, штовхачів, заглушок, фрагментів піроболтів тощо) та засобів їхнього виведення;

- викиди із космічних апаратів та засобів їх виведення продуктів роботи рушійних установок, незгорілого твердого палива, рідких речовин, які не випаровуються або повільно випаровуються;

- орбітальні ступені ракет-носіїв, розгінних блоків і космічних апаратів по завершенні їхнього активного функціонування;

- руйнування космічних об'єктів внаслідок зіткнень на орбіті (з частинами природного походження або з об'єктами космічного сміття);

- ерозія матеріалів із зовнішніх поверхонь космічних апаратів і засобів виведення;

- тросові системи, що відокремлюються від космічних апаратів після використання;

- викиди у космічний простір засобів забезпечення життєдіяльності пілотованих космічних апаратів [Правила, 2006].

Найбільший «внесок» у засмічення навколоземного космічного простору зроблено Російською Федерацією (6 213 об’єктів космічного сміття), США (5 120) та Китаєм (3 621) [События, 2016: 8]. Слід відзначити й внесок України у засмічення космічного простору: українські супутники дистанційного зондування Землі (Січ-1, Січ-1M, Січ-2) також перетворилися в об'єкти космічного сміття.

Значна частина об'єктів космічного сміття (особливо невеликих розмірів та ваги), розташованих на низькій навколоземній орбіті (200-2000 км), внаслідок гальмівного впливу верхніх шарів атмосфери сходить 3 орбіти та згорає в щільних шарах атмосфери. Ефективність відповідних природних процесів «самоліквідації» об'єктів космічного сміття залежить від конкретної висоти знаходження космічного сміття у навколоземному космічному просторі, його ваги. Особливо це стосується космічних об'єктів на геостаціонарній орбіті (на висоті 35786 км над рівнем моря), які будуть там знаходитися сотні, мільйони років [Сборник, 2013: 31]. Фрагменти великих космічних об'єктів та об'єктів космічного сміття, як показує космічна практика, під час сходження з низької орбіти повністю не згорають в атмосфері. 
На початку космічної ери проблема утворення космічного сміття не мала глобальних масштабів і не становила реальної небезпеки для провадження космічної діяльності, оскільки кількість держав, які здійснювали запуски космічних об'єктів, була обмежена (повним циклом провадження космічної діяльності тоді володіли СРСР та США). При цьому імовірність зіткнення космічних об'єктів з об'єктами космічним сміттям рахувалася низькою.

На міжнародному рівні термін «космічне сміття» вперше було вжито в 1982 році на Другій космічній конференції ООН з окресленням проблеми космічного сміття та необхідності їі вирішення у майбутньому [Доклад, 1982] задля забезпечення сталого розвитку космічної діяльності в інтересах теперішніх і майбутніх поколінь.

В 1989 році Генеральна Асамблея ООН офіційно констатувала, що питання про космічне сміття викликає занепокоєння усіх держав [Резолюция, 1989]. У зв'язку з цим було рекомендовано зосередити увагу на всіх аспектах, що стосуються охорони космічного простору, особливо тих, які можуть мати наслідки для навколишнього середовища на Землі. Незважаючи на прогнозування виникнення техніко-юридичних проблем по факту засмічення космічного простору, необхідний інструментарій міжнародного космічного права для охорони навколоземного космічного простору досі не сформований.

Протягом багатьох років проблема техногенного засмічення космічного простору перебуває у центрі уваги Комітету ООН з використання космічного простору в мирних цілях. Його юридичним і науково-технічним підкомітетами здійснюються комплексні дослідження проблеми техногенного засмічення космічного простору у напрямку забезпечення прогресивного розвитку міжнародного космічного права. Результатом їхньої роботи 3 визначення техніко-юридичних способів мінімізації утворення космічного сміття стало ухвалення в 2007 році Керівних принципів щодо запобігання утворення космічного сміття (далі - Керівні принципи), які схвалені резолюцією Генеральної Асамблеї ООН №A/RES/62/217 від 01.02.2008 р. [Руководящие принципы, 2008]. Акцент зроблено лише на «запобіганні» його утворення, оскільки на даному етапі розвитку в силу техніко-конструктивних особливостей експлуатації ракетно-космічної техніки неможливо повністю виключити утворення космічного сміття. Закладені в цьому документі технічні умови мають загальне позитивне значення для попередження утворення космічного сміття. Проте, міжнародно-правова проблема реалізації Керівних принципів полягає у тому, що вони підлягають застосуванню державами виключно у добровільному порядку. Тобто, Керівні принципи не є юридично обов'язковими до виконання суб'єктами міжнародного космічного права згідно з міжнародним космічним правом [Семеняка, 2015: 346]. Вони належать до категорії актів «м’якого права» (soft law), що мають рекомендаційний характер.

Правова конструкція Керівних принципів грунтується на забезпеченні їхньої реалізації державами добровільно через національні або застосовані ними механізми шляхом використання відповідних практик і процедур запобігання утворення космічного сміття. Отож юридичний акцент щодо обов'язкового застосування Керівних принципів переміщено на рівень національного космічного законодавства.

Сучасною тенденцією розвитку космічного права $є$ формування національно-правових механізмів щодо забезпечення охорони навколоземного космічного простору на підставі Керівних принципів. Саме на рівні національного космічного законодавства формуються конкретні правові механізми щодо мінімізації утворення космічного сміття. Вирішення питань мінімізації утворення космічного сміття має здійснюватися суб'єкта- 
ми космічної діяльності на усіх стадіях її провадження (проектування, виготовлення та експлуатації космічної техніки).

Як свідчить проведене дослідження, впровадження у космічне законодавство рекомендованого міжнародно-правового інструменту щодо запобігання утворення космічного сміття передбачається в національному космічному праві (зокрема, США, Російської Федерації, України та деяких країнах Свропейського Союзу) шляхом визначення конкретних правових основ запобігання техногенному засміченню космічного простору. Важливо відзначити, що за відсутності міжнародно-правового визначення терміну «космічне сміття», цей термін має різне техніко-юридичне наповнення на рівні національного космічного законодавства, що обумовлює особливості реалізації заходів 3 мінімізації утворення космічного сміття, застосування міжнародної відповідальності за завдану шкоду тощо.

Разом 3 цим національне космічне законодавство передбачає особливості реалізації технічних вимог з обмеження техногенного засмічення навколоземного космічного простору. Наприклад, вимоги щодо обмеження засмічення навколоземного космічного простору при експлуатації космічної техніки в Україні не підлягають застосуванню до космічних об’єктів військового та подвійного призначення [Правила, 2006].

Незважаючи на певні зусилля щодо запобігання утворення космічного простору, кількість об'єктів космічного сміття в навколоземному космічному простору постійно зростає, що зумовлює збільшення імовірності ризиків зіткнення об'єктів космічного сміття один з одним, з функціонуючими космічними апаратами, падіння на Землю тощо. Очевидно, що лише заходів 3 мінімізації утворення космічного сміття явно недостатньо для гарантування довгострокового та безперешкодного доступу суб'єктів космічної діяльності до навколоземного космічного простору, його дослідження та використання в інтересах теперішніх та майбутніх поколінь.

Національно-правові заходи спрямовані на мінімізацію утворення космічного сміття, при цьому ними не розв’язується проблема очищення космічного простору від об'єктів техногенного походження. Ї̈ї невирішеність зберігає високою імовірність насамперед можливих зіткнень функціонуючих космічних апаратів 3 космічним сміттям. Ці обставини негативного характеру актуалізують потребу розв'язання проблеми видалення космічного сміття. Це є складною міжнародно-правовою проблемою, оскільки нормами і принципами сучасного міжнародного космічного права не передбачено обов'язку суб'єктів міжнародних правовідносин щодо очищення навколоземного космічного простору. Іншими словами, утворення та існування космічного сміття не зумовлює виникнення міжнародного зобов'язання з його видалення.

У практиці міжнародного космічного права немає прецедентів з реалізації космічних проектів з видалення космічного сміття, хоча й розроблено значну кількість науково-обгрунтованих технічних рішень щодо очищення навколоземного космічного простору видалення космічного сміття. Проте вони знаходяться на стадії апробації. Одним із таких рішень є спільний українсько-європейський космічний проект «LEOSWEEP» 3 активного видалення космічного сміття, що заплановано реалізувати за допомогою космічного апарату з використанням іонного променя [Алпатов, 2015: 56-61]. Запуск даного космічного апарату передбачає здійснення безконтактного видалення космічного сміття 3 низьких навколоземних орбіт шляхом зміни орбіти розташування об'єкту космічного сміття зі спрямуванням в атмосферу задля його згорання або переміщення у місця «захоронення» в космічному просторі (у випадку, якщо за проведеними розрахунками об'єкт 
космічного сміття повністю не згорить в атмосфері та існує ризик його неконтрольованого падіння на Землю).

У процесі реалізації космічних проектів з очищення навколоземного космічного простору важливого значення набуває вирішення цілого кола міжнародно-правових питань, зокрема, міжнародної відповідальності за шкоду, заподіяну третім особам (державі, іiі фізичним або юридичним особам).

\section{Висновки}

1. Запорукою сталого розвитку космічної діяльності в інтересах теперішніх і майбутніх поколінь важливою є координація зусиль суб'єктів міжнародного космічного права у напрямку впровадження ефективних міжнародно-правових інструментів, спрямованих на правову охорону навколоземного космічного простору від техногенного засмічення, які будуть обов'язкові до виконання усіма суб'єктами космічних правовідносин.

2. У контексті сучасного застосування космічної техніки та використання космічного простору, перспективним напрямком міжнародно-правового забезпечення розв'язання проблеми правової охорони космічного простору має стати розробка та прийняття під егідою ООН Конвенції про запобігання утворення космічного сміття та очищення навколоземного космічного простору. Цей документ має врегулювати понятійно-термінологічний апарат, систему та порядок реєстрації космічного сміття, відносини щодо контролю й управління космічним рухом, права власності на об'єкти космічного сміття, юридичну процедуру видалення космічного сміття та закріпити міжнародно-правову відповідальність за техногенне засмічення космічного простору.

Особлива увага має бути приділена розробці міжнародно-правового механізму моніторингу (спостереження) за навколоземним космічним простором, включаючи за польотами космічних апаратів та повідомлення (оповіщення) суб'єктів міжнародного космічного права з метою запобігання зіткненням космічних апаратів з нефункціонуючими об'єктами космічного сміття та ін.

\section{Література}

Online Index of Objects Launched into Outer Space. http://www.unoosa.org/oosa/osoindex/ search-ng.jspx?lf_id=

События в околоземном космическом пространстве. Центральный научноисследовательский институт машиностроения. Выпуск 1 (68), 2016. - 41 с.

Шемшученко, Ю. С. Космічне право: Підручник. Київ: Вид-во «Юридична думка», 2012. О разработке мер по обеспечению планетарной защиты от космических рисков и угроз: сборник по итогам круглого стола, 12 марта 2013 года, Москва /Совет Федерации Федерального Собрания Российской Федерации. Москва, 2013.

Доклад второй Конференичи Организации Объединенных Наџий по исследованию и использованию космического пространства в мирных иелях, Вена, 9-21 августа 1982 года. http://www.unoosa.org/res/oosadoc/data/documents/1982/aconf/ aconf_10110_0_html/A_CONF101_10R.pdf

Резолючия Генеральной Ассамблеи ООН от 08.12 .1989 г. № 44/46 «Международное сотрудничество в использовании космического пространства в мирных изелях». http://daccess-dds-ny.un.org/doc/RESOLUTION/GEN/NR0/552/87/IMG/NR055287. pdf?OpenElement 
Руководящие принщипь Комитета по использованию космического пространства 6 мирных иеелях по предупреждению образования космического мусора. http://www. un.org/ru/documents/decl_conv/conventions/space_debris.shtml.

Правила космічної діяльності в Украӥни (УРКТ - 11.03). Обмеження засмічення навколоземного космічного простору при експлуатації космічної техніки: наказ Національного космічного агентства України від 19.07.2006 р. № 204. Київ: НКАУ, 2006.

Семеняка, В.В. Актуальні проблеми міжнародно-правової охорони космічного простору від техногенного засмічення. Часопис Київького університету права, № 4, 2015 : 344-347

Алпатов, А. П., К. Бомбарделли, С. В. Хорошилов. Концепция активного удаления космического мусора. Космічна наука і технологія. Т. 21, № 6, 2015: 56-61

\section{$\mathbb{E}[\mathbb{l}$ References}

Online Index of Objects Launched into Outer Space. http://www.unoosa.org/oosa/osoindex/ search-ng.jspx?lf_id=

Events in near-Earth space: Central Research Institute of Mechanical Engineering. 2016 - Issue 1 (68). - $41 \mathrm{~s}$.

Shemshuchenko, Yu.S. Space Law: Textbook. — K .: "Legal Opinion”, 2012.

On the development of measures for the protection of planetary protection against space risks and threats: a compilation of the results of the round table, March 12, 2013, Moscow / Council of Federation of the Federal Assembly of the Russian Federation. - Moscow, 2013.

Report of the Second United Nations Conference Nations for the Exploration and Use of Outer Space peaceful purposes, Vienna, August 9-21, 1982. http: //www.unoosa.org/res/oosadoc/ data/documents/1982/aconf/aconf_10110_0_html/A_CONF101_10R.pdf

Resolution of the General Assembly of the United Nations dated $\overline{0} 8 / 12 / 1989$ No. 44/46 "International cooperation in the peaceful uses of outer space”. http://daccess-dds-ny. un.org/doc/RESOLUTION/GEN/NR0/552/87/IMG/NR055287.pdf?OpenElement

See: Guidelines of the Committee on the Peaceful Uses of Outer Space for the Prevention of the Development of Space Debris [Electronic Resource] — Access Mode: http://www. un.org/en/documents/decl_conv/conventions/space_debris.shtml.

The rules of space activity in Ukraine (URCT - 11.03). Limitation of the contamination of near-Earth space during the operation of space technology: Order of the National Space Agency of Ukraine dated July 19, 2006, No. 204. — K .: NSAU, 2006. — 18 s.

Semenyaka, V.V. Actual problems of international legal protection of space from technogenic clogging / Journal of the Kyiv University of Law, Kyiv. No. 4 - 2015: 344-347

See: A.P. Alpatov, K. Bombardelli, S.V. Khoroshilov. The concept of active removal of space debris / Space science and technology.- T. 21. — No. 6. - 2015: 56-61 